\title{
Experimental Study of the New Non-Opioid Analgesic Pyrodazol and Ketorolac in the Rats
}

\author{
Oleh Yadlovskiy , Tatiana Bukhtiarova, Anatoliy Demchenko
}

State Institution Institute of Pharmacology and Toxicology of National Academy of Medical Sciences of Ukraine, Eugene Potie str. 14, Kiev 03680, Ukraine

\author{
Citation: Yadlovskiy O, Bukhtiarova $T$ \\ Demchenko A. Experimental Study of the New \\ Non-Opioid Analgesic Pyrodazol and Ketorolac \\ in the Rats. Maced J Med Sci. 2013 Sep 15 \\ 6(3):227-231. http://dx.doi.org/10.3889/MJMS.1857- \\ 5773.2013.0314. \\ Key words: pyrodazol; morphine; ketorolac; \\ analgesia. \\ "Correspondence: Dr. Oleh Yadlovskiy. State \\ Institution Institute of Pharmacology and \\ Toxicology of National Academy of Medica \\ Sciences of Ukraine, Eugene Potie str. 14, Kiev \\ Received: 17-Jul-2013; Revised: 21-Aug- \\ 2013; Accepted: 24-Aug-2013; Online first: \\ 04-Sep-2013 \\ Copyright: () 2013 Yadlovskiy O. This is an \\ open-access article distributed under the terms \\ of the Creative Commons Attribution License, \\ which permits unrestricted use, distribution, \\ and reproduction in any medium, provided the \\ original author and source are credited. \\ Competing Interests: The authors have \\ declared that no competing interests exist.
}

\section{Abstract}

Aim: To search the new analgesics we studied the antinociceptive activity of the new derivative $5 \mathrm{H}$ pyrrolo [1,2-a] ᄀimidazole in comparison with this of the morphine and ketorolac.

Material and Methods: The analgesia was evaluated on hot plate and tail-flick thermal nociceptive stimulation models by intragastric administration of ketorolac and by intramuscular injection of morphine.

Results: On the hot plate model $\mathrm{ED}_{50}$ value was per body weight $0.34(0.18-0.63) \mathrm{mg} / \mathrm{kg}$ of the pyrodazol /i.g, $1.00(0.59-1.70) \mathrm{mg} / \mathrm{kg} /$ of the ketorolac/ i. g. in 90 minutes post administration. On the hot plate model in $0.3-1.3 \mathrm{mg} / \mathrm{kg} / \mathrm{doses}$ i.m the pirodazol is similar to morphine hydrochloride in dose $2.5 \mathrm{mg} / \mathrm{kg}$ i.m. On the tail-flick model $\mathrm{ED}_{50}$ values of the pyrodazol and ketorolac are 1.9 $(1.12$ - 3.23$) \mathrm{mg} / \mathrm{kg} / \mathrm{i} . \mathrm{g}$ and $3.0(2.08$ - 4.32) $\mathrm{mg} / \mathrm{kg} / \mathrm{i} . \mathrm{g}$, respectively.

Conclusion: The obtained data may allow to suggest that on thermal nociceptive stimulation models the pyrodazol exceeds the ketorolac and on the hot plate models it is similar to the morphine hydrochloride.

\section{Introduction}

Pain syndromes are the most widespread and accompany many diseases $[3,11]$. Therefore, the problem of pain and adequate pain relief is one of the most important tasks of clinical and experimental medicine being the subject of applied and basic research. Among the wide range of methods of analgesia (surgical, physical, psychological, etc.), drug therapy is in central place. Among the many pain relievers (opioids, non-steroidal antiinflammatory drugs (NSAIDs), narcotic (NA) and adjuvant analgesics), there are no analgesics, which would better fit the clinic. The use of an opioid analgesics is limited despite its high efficiency because of severe side effects, among which should be marked the physical and psychical dependence, addiction [1].
Therefore, their use is limited and regulated. Non-narcotic analgesics and NSAIDs are usually effective for mild and moderate pain, however they could cause a number of serious side effects (hepatonephrotoxicity haemotoxicity, etc.) [14]. The adjuvant analgesics (á2-adrenomimetics, m-anticholinergics $(\mathrm{m}$ choline blockers), etc.) actually are not analgesics, they can't solve fully this problem (may develop the significant efficacy in certain pain - neuropathic, spasmodic pain, etc.) [2]. Therefore it is important to find the new analgesics that exceed the existing analogues in efficacy and/or safety. The nitrogen heterocycles are interest of this aspect. For the last decades the number of analgesics containing nitric heterocyclic ring such as ketorolac, edotolak, likofelon and others are used in medical practice for pain 
treatment $[7,15]$. At present we are in active search of the new analgesics among various classes of nitrogen-containing heterocycles, including derivatives of pyrrole and imidazole [7, 10].

The aim of this study was to make a profound investigation of the antinociceptive activity of a novel $5 \mathrm{H}$-pyrrollo[1,2-a] imidazole-pyrodazol-(1,3-di(4 ${ }^{1}$ etoxiphenyl)-6,7-dihydro-5H-pyrrollo[1,2-a] imidazole on thermal nociceptive stimulating models.

\section{Materials and Methods}

\section{Animals}

Female Wistar rats (150-200 g) and nonlinear mice (18-22 g) were used. The animals were housed in a quarantine facility for 7 days before the experiment was started. Throughout the experiment, the animals were randomised in groups of four in cages with the bedding composed of wood shavings (exchanged daily). The animals had free access to a standard commercial diet and water. The animals were kept under a stable regimen of $12 \mathrm{~h}$ light/12 $\mathrm{h}$ darkness. All studies were performed under the requirements HEC of the Ministry of Health of Ukraine and the rules of the "European Convention for the protection of vertebrate animals are used with experimental and other scientific purpose" (Strasbourg, 1986).

\section{Substances}

Ketorolac tromethamine (ketorolac) substance (JSC "Lek-Chem» Ukraine), morphine hydrochloride (morphine) substance, produced by MAKFARLAN Ltd, United Kingdom, pyrodazol substance, (synthesized in the Department of Synthesis of biologically active substances at SE "Institute of pharmacology and toxicology for AMS of Ukraine ", Kiev). Pyrodazol was administered once orally (p. o.) or intramuscularly (i.m.), in a form of the aqueous-ethanol emulsion. Ketorolac was administered once p.o. in a form of aqueous solution. Morphine hydrochloride was administered i.m. in a form of aqueous solution.

\section{Analgesia}

Evaluation of analgesic activity in the experiment was carried out on thermal models nociceptive stimulating "hot plate" [5] and tail-flick [4].The analgesic activity founded on the change of the latency of "paw licking" (hot plate) and of the flick of the tail (tail-flick) was evaluated. At the same time, we determined the percentage of change of the latent period of the reaction relative to the threshold of the reaction at the initial (point).

The hot-plate test was assessed on groups of 5 mice. The temperature of a metal surface was maintained at $55 \pm 0.2^{\circ} \mathrm{C}$. Latency to a discomfort reaction (licking paws or jumping) was determined before and after drug administration. The cut-off time was $20 \mathrm{~s}$. The latency was recorded before and 0.5, 1, $1.5,2,3$, and 24 hours following p.o. administration of the agents (ketorolac and pyrodazol). The prolongation of the latency times compared with the values of the initial was used for statistical comparison. Both the pyrodazol in doses $0.1,0.5,1$, 1.5 or $3 \mathrm{mg} / \mathrm{kg}$ and the ketorolac in doses $0.5,1,2.5$ or $5 \mathrm{mg} / \mathrm{kg}$ once were p.o. administration to the appropriate animal groups. Comparative evaluation of analgesic effect of the pyrodazol and morphine was performed on a hot plate model after a single dose of i.m. injection in $0.3,0.65,1.3$, or $2.5 \mathrm{mg} / \mathrm{kg}$ (pyrodazol) and $2.5 \mathrm{mg} / \mathrm{kg}$ (morphine). Latency was recorded before and $0.5,1,1.5,2$ hours following administration of the agents.

The tail-flick test was assessed on groups of 5 rats. The pyrodazol as the ketorolac were administered p.o. doses $1,2.5$ or $5 \mathrm{mg} / \mathrm{kg}$. The tail flick latency was assessed by the analgesiometer (Ugo Baile, Italy). The strength of the current passing through the naked nicrome wire was kept constant at 6 Amps. The distance between the heat source and the tail skin was $1.5 \mathrm{~cm}$. The site of application of the radiant heat in the tail was maintained at $2.5 \mathrm{~cm}$, measured from the root of the tail. The cut-off reaction time was fixed at $15 \mathrm{sec}$ to avoid tissue damage. Latency was recorded before and $0.5,1,1.5,2,2.5$ and 3hours following administration of the agents.

The calculated pyrodazol and ketorolac $E_{50}$ values on the studied models using the Litchfil and Wilcoxon method [6].

The results were analyzed for statistical significance using variational statistics (t-test) OriginPro 8.0 (originLab Corporation, USA) [13].

\section{Results}

In the hot plate test the pyrodazol shows the significant analgesic effect $(P>0.05)$ of $0.5-3 \mathrm{mg} / \mathrm{kg}$ doses (Fig. 1).

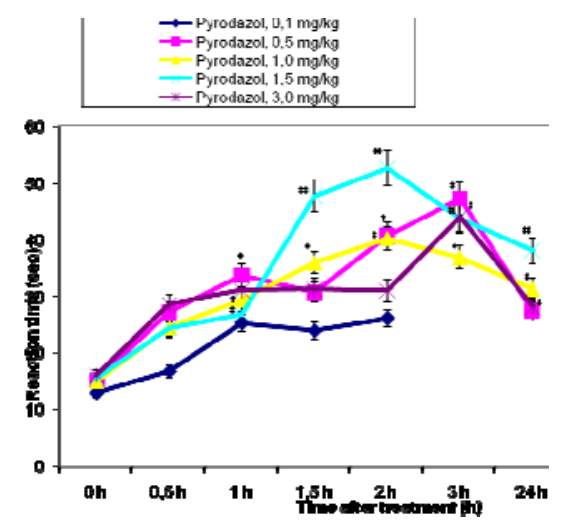

Figure 1: Effect of the pyrodazol (p.o.) on pain threshold of mice in the hot-plate test. Each point represents the mean \pm S.E.M. of reaction time for $n=5$ experiments on mice. ${ }^{*} P<0.05$; ${ }^{* *} P<0.01$ compared to initial, (t-test). 
The tendency for increase of latency response $57.16-78.95 \%$ (or $27.20 \pm 8.42$ to $27.20 \pm$ $8.42 \mathrm{sec}$ ) in comparison with the baseline is recorded in 30 minutes post administration of the pyrodazol. The dose-dependent increase of the latency of reaction was recorded in the subsequent term $(60-120$ min) of monitoring. The analgesia peak was observed in 120 min after injection with pyrodazol. It is important that a validity of the increase in the latent period of the reaction (by $73.43145 .55 \%$ or $28.10 \pm 4.87$ to 38.06 $\pm 5.69 \mathrm{sec}$ as compared to the initial) is recoded in 24 hours after administration of the pyrodazol at doses of 1-3 $\mathrm{mg} / \mathrm{kg}$.

The validity of the increase in the latent period of the reaction by $48.95-76.17 \%$ (or $16.95 \pm 2.83$ to $27.20 \pm 3.50 \mathrm{sec}$ ) was observed in $30 \mathrm{~min}$ after ketorolac's administration in the doses of $0.5-1$ $\mathrm{mg} / \mathrm{kg}$ (Fig. 2).

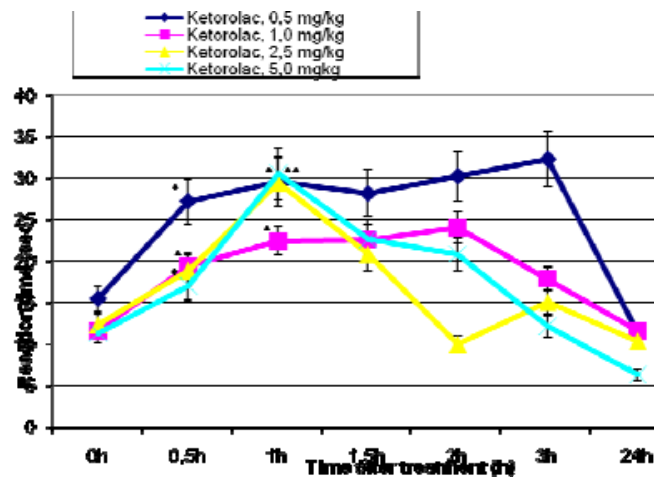

Figure 2: Effect of the ketorolac (p.o.) on pain threshold of mice in the hot-plate test. Each point represents the mean \pm S.E.M. of reaction time for $n=5$ experiments on mice. ${ }^{*} P<0.05$; ${ }^{* *} P<0.01$ compared to initial, (t-test).

In 60 minutes after the administration in doses of $0.5-5 \mathrm{mg} / \mathrm{kg}$, the effect of ketorolac achieved the analgesia peak (latency of reaction is increased by $91.70 \%-167.84 \%$ (or $29.60 \pm 3.36$ to $30.48 \pm 5.84$ $\mathrm{sec}$ ) in comparison with the initial dose- dependent latency reaction). At the appropriate doses it is comparable to this of the pyrodazol in the given period of observation. In the subsequent period of the observation, the analgetic effect of the ketorolac is rapidly reduced, unlike this of the pyrodazol.

The comparative antinociceptive study of the pyrodazol (i.m.) and of the morphine (i.m.) on this model showed that the morphine when was administrate to mice in conditionally therapeutic dose of $2.5 \mathrm{mg} / \mathrm{kg}$ decreased the pain threshold by $207.8 \%$ (46.42 $\pm 13.60 \mathrm{sec})$ in $30 \mathrm{~min}$ after the administration. In following observation period we registered the significant antinociceptive effect of the morphine hydrochloride (reduction of pain threshold by $103 \%$ $178.9 \%(46.42 \pm 13.60 \mathrm{sec})$, in 60 and $90 \mathrm{~min}$ of observation respectively) (Fig. 3 ). On the nociceptive stimulating tail-flick model the pyrodazol and the ketorolac showed a significant dose-dependent analgetic effect already in 30 minutes after the administration (Fig. 4, 5).

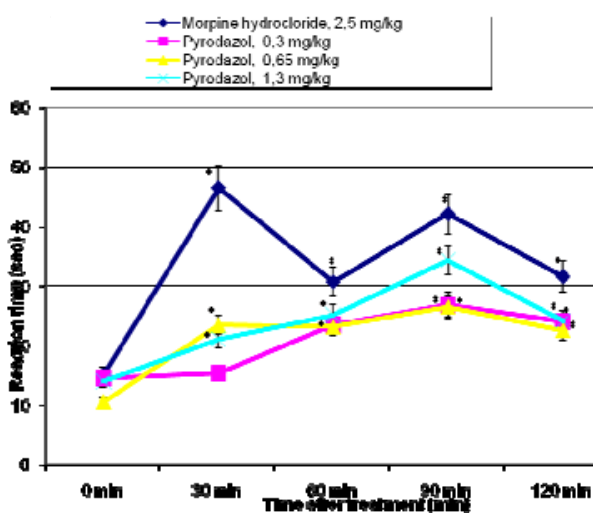

Figure 3: Effect of the pyrodazol and morphine hydrochloride (i.m.) on pain threshold of mice in the hot-plate test. Each point represents the mean \pm S.E.M. of reaction time for $n=5$ experiments on mice. ${ }^{*} P<0.05$, compared to initial, (t-test).

The rapidity of achievement of the analgesia peak is also dose-dependent. Thus as for the ketorolac the peak of the analgetic effect was registered after the administration of the drug in 30 minutes in dose $5 \mathrm{mg} / \mathrm{kg}$ (increase of latency reaction by $141.26 \%(9.94 \pm 2.09 \mathrm{sec})$ as compared to initial) and in $2.5 \mathrm{mg} / \mathrm{kg}$ of the drug in $60 \mathrm{~min}$ following the drug administration (increase latency reaction by by $73.85 \%$ (7.58 $\pm 0.92 \mathrm{sec})$ as compared to initial).

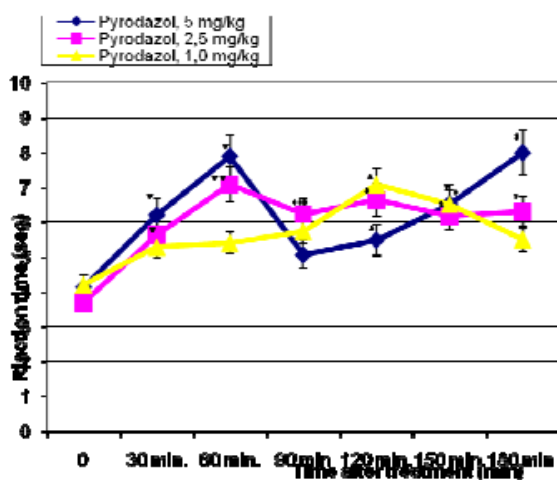

Figure 4: Effect of the pyrodazol (p.o.) on pain threshold of white rats in the tail flick test. Each point represents the mean \pm S.E.M. of reaction time for $n=5$ experiments on rats. ${ }^{*} P<0.05 ;{ }^{*} P<0.01$; ${ }^{* \star *} P<0.001$ - compared to initial, (t-test).

In the following observation period (60 - 180 min after injection) the ketorolac analgetic effect decreased as described as: at dose $5 \mathrm{mg} / \mathrm{kg}$ the pain threshold decreased by $55.83 \%(6.42 \pm 0.64 \mathrm{sec})$ as compared to initial at dose $2.5 \mathrm{mg} / \mathrm{kg}$ - by $43.81 \%$. Reduction of the dose up to $1 \mathrm{mg} / \mathrm{kg}$ of the ketorolac discontinued the development of the analgesic effect and the state of hyperalgesia was observed (Fig. 5). The pyrodazol showed the significant analgesic effect (the validity of the increase in the latent period of the reaction is by $50.12 \%$ and $52.27 \%$ or $6.20 \pm 0.97$ and $5.63 \pm 0.90 \mathrm{sec}$ respectively) after 30 minutes following the administration in 2.5 - $5 \mathrm{mg} / \mathrm{kg}$ doses body weight, peak of the effect (the validity of the increase in the latent period of the reaction is $90.80 \%$ and $91.87 \%$ or $7.88 \pm 1.94$ and $7.08 \pm 1.46$ respec- 
tively) was achieved in 60 minutes of observation that exceeds the effect of the ketorolac recorded in $60 \mathrm{~min}$. following the introduction. Considerable analgesic effect of the ketorolac in 2.5 and $5 \mathrm{mg} / \mathrm{kg}$ doses is conserved up to 180 minutes of observation.

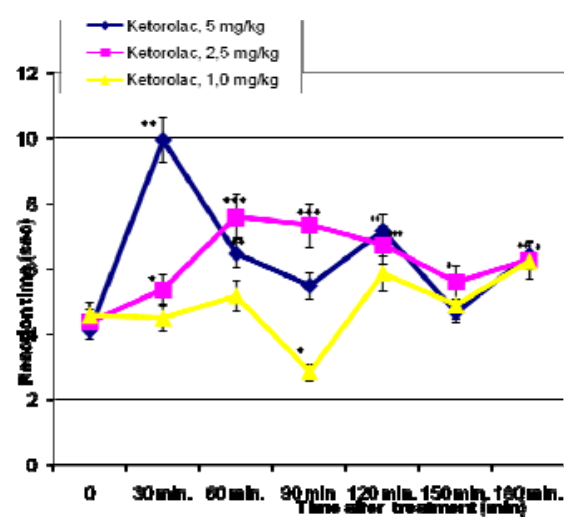

Figure 5: Effect of the ketorolac (p.o.) on pain threshold of mice in the hot-plate test. Each point represents the mean \pm S.E.M. of reaction time for $n=5$ experiments on rats. . ${ }^{\star} P<0.05 ;{ }^{* *} P<0.01$; ${ }^{\star \star \star} P<0.001$ - compared to initial, (t-test).

\section{Discussion}

The study was performed in comparative aspect with ketorolac, because it is one of the most potent non-narcotic analgesic used in clinic and has a fragmentary similarity to the pyrodazol molecule [1]. We carried out a study of analgetic effects of the pyrodazol in comparison with the morphine as the pyrodazol is one of the most powerful analgesic. The hot plate model describes the supraspinal level of nociception, which may allow to define the central component of the antinociceptive activity of the analgesic. This test characterizes the effectiveness of the compound as to suppression of a somatic superficial and acute pain. In the studied dose range the pyrodazol exceeds the ketorolac in efficiency, as it is shown by magnitude and by duration of the analgetic effect in this experiment. $E D_{50}$ values of the pyrodazol on the hot plate model are 0.79 (0.34 1.82) $\mathrm{mg} / \mathrm{kg}$ in $60 \mathrm{~min}$ after the administration and $0.34(0.18-0.63) \mathrm{mg} / \mathrm{kg}$ in $90 \mathrm{~min}$ after the administration, $\mathrm{ED}_{50}$ values of the ketorolac at these terms of the experiment are $0.44(0.16-1.18) \mathrm{mg} / \mathrm{kg}$ and $1.00(0.59-1.70) \mathrm{mg} / \mathrm{kg}$. In comparing the pyrodazol antinociceptive effect with this of the morphine, the pirodazol appeared on the hot plate model to be as effective as morphine, an analgetic mechanism of action of which is associated with an effect on CNS $\mu$-opioid receptors. It is known that stimulation by the morphine and by its opioid receptors derivatives causes an inhibition of interneuronic excitation transmission at the level of posterior horns of the spinal cord. It is also important that the morphine effects on supraspinal nuclei are involved in the descending control of neuronal activity of the posterior horns of the spinal cord. The morphine also effects on neurons of the brain as well as on limbic system and on hypothalamus [10, 12]. However the antinociceptive effect of the pyrodazol is not modeled by naloxone opioid receptor antagonist, that may allow to suggest that mechanism of action of the analgesic is non-opioid $[17,18]$. In all probability it can be assumed that the antinociceptive effect of the pyrodazol is realized through above mentioned structures of the brain by modulation of non-opioid mechanisms (adrenergic, serotoninergic, etc.). It is important that the pyrodazol effect being equal on intensity to this of the morphine (reduction of pain threshold response is $119.6 \%$ and $151.1 \%$ in 60 and 90 minutes of observation respectively) at administration showed its effectiveness in a lower dose $(0.65 \mathrm{mg} / \mathrm{kg}$ or $0.002 \mathrm{mM} / \mathrm{kg})$. The obtained data on the whole may allow to suggest that the pain response of the pyrodazol observed on the thermal nociceptive stimulating model (hot plate method) demonstrated the central component and could exhibit the expressed analgetic effect comparable to this of morphine hydrochloride and ketorolac and exceeds the ketorolak during the analgetic effect.

Tail-flick method is used to evaluate the supraspinal level of pain reaction [9]. The pyrodazol activity in comparison with this of the ketorolac was studied in the dynamics in experimental female rats (5 per group) which received a single dose of the drug $p$. o. The study was conducted in the females, since the females are more sensitive for the model [16]. Pain stimulation was applied to the distal part of tip of the tail, as it is known this area is more sensitive in comparison with the proximal part. On this nociceptive stimuli model the $E D_{50}$ values calculated for $60 \mathrm{~min}$. after the administration of the pyrodazol and ketorolac were $1.9(1.12-3.23) \mathrm{mg} / \mathrm{kg}$ and $3.0(2.08-4.32)$ $\mathrm{mg} / \mathrm{kg}$ in $90 \mathrm{~min}-4.0(2.1$ - 7.6) $\mathrm{mg} / \mathrm{kg}$ and $3.6(2.9-$ 4.43) $\mathrm{mg} / \mathrm{kg}$ respectively. The obtained results show the higher activity of the pyrodazol in comparison with this of the ketorolac. It is known that a nociception is regulated by a number of control mechanisms, including a spinal (segmental or heterosegmental). Pyrodazol administration can provide the increase of the latency response on the tail-flick model due to its effect on posterior roots. [16] Spino-bulbo-spinal circuit could mediate it, for example [8].

It should be noted that the thermal nociceptive stimulating studies (hot plate, tail-flick) are characterized by the central and not peripheral analgetic level of action but they have disadvantage that sedatives, myorelaxants and psychotomimetics can cause a false antinociceptive effect. [18]. Therefore the further research studies on pyrodazol antinociceptive activity are required.

Conclusion: We detected on the models of thermal nociceptive stimuli (hot plate and tail-flick) in single introduction p.o. that pyrodazol exceeds the ketorolac in the antinociceptive activity. In intramuscular administration on the hot plate model, pyrodazol posesses an analgesic potency equal to this of the morphine hydrochloride. 


\section{References}

1. Andersen KV, Nikolajsen L, Haraldsted V, Odgaard A, Soballe K. Local infiltration analgesia for total knee arthroplasty: should ketorolac be added?. $\mathrm{Br} J$ Anaesth. 2013 (doi: 10.1093/bja/aet030)

2. Barkin, Robert L. Barkin, D Pharmacologic Management of Acute and Chronic Pain: Focus on Drug Interactions and Patient-Specific Pharmacotherapeutic Selection.Southern Medical Journal. 2001; 94 (8): 756-770.

3. Blyth FM, March LM, Brnabic AJM, Jorm LR, Williamson M, Cousins MJ. Chronic pain in Australia: a prevalence study. Pain. 2001; 89(2): 127-134

4. Compton WM ,Volkow ND Major increases in opioid analgesic abuse in the United States: Concerns and strategies. Drug and Alcohol Dependence. 2006; 81:103-107.

5. D`Amoue FE. A method for determining lose of pain sensation . J. Pharmacol. Exp. Ther. 1941;72: 74.

6. Gad CS, Chengelis CP. Acute Toxicology Testing, Second Edition San Diego Academic Press, 1997:534.

7. Handley DA, Carvoni P, McCray JE, McCullough JR. Preclinical Enantioselective Pharmacology of (R)- and (S)Ketorolac. J Clin Pharmacol. 1998; 38: 25-35.

8. King TE, Joynes RL, Grau JW Tail-flick test: II. The role of supraspinal systems and avoidance learning. Behav Neurosci . 1997;111:754-767.

9. Komlos E, Porsresr J, Knole J.Morfin - prostigmin synergismus. Az. Acta. Phisiologica. Acad. Scient. Hungaricae.-1950;1: 77-83.

10. Lugo RA, Kern SE. Clinical pharmacokinetics of morphine. J. Pain Palliat Care Pharmacother. 2002; 16(4): 5-18.

11. Mathias SD, Kuppermann M, Liberman RF, Lipschutz RC, Steege JF. Chronic pelvic pain: prevalence, health-related quality of life, and economic correlates.Obstetrics \& Gynecology. 1996; 87 (3): 321-327.

12. Mellon RD, Bayer BM. Evidence for central opioid receptors in the immunomodulatory effects of morphine: review of potential mechanism(s) of action. J. Neuroimmunol. 1998;83 (1-2): 1928.

13. OriginLab $\circledast$ Data Analysis and Graphiny Software, 2012 (http://www.originlab.com/)

14. Rainsford K.D Profile and mechanisms of gastrointestinal and other side effects of nonsteroidal anti-inflammatory drugs (NSAIDs).The American Journal of Medicine. 1999; 107 (6): 27-35.

15. Scher L, Hornig M, Pergola C. The molecular mechanism of the inhibition by licofelone of the biosynthesis of 5lipoxygenase products. British Journal of Pharmacology. 2007;152(4): 471-480.

16. Wiesenfeld-Hallin Z, Hao J-X, Xu X-J, Aldskogius $H$, Seiger $A /$ Genetic factors influence the development of mechanical hypersensitivity, motor deficits and morphological amage after transient spinal cord ischemia in the rat. Pain. 1993;55: 235241.

17. Yadlovskyy OE, Movchan OM. Pharmacological analysis of the opioid component action of analgesic pyrodazol / Pharmacology and medical toxicology. 2011;.11(3): 73-77.

18. Vogel WH. Drug Discovery and Evaluation: Pharmacological Assays. Second Edition. (http://web.squ.edu.om/medLib/MED_CD/E_CDs/Drug\%20Discovery\%20and\%20Evaluatu on $\% 202002 /$ start.pdf) 